Contract No. and Disclaimer:

This manuscript has been authored by Savannah River Nuclear Solutions, LLC under Contract No. DE-AC09-08SR22470 with the U.S. Department of Energy. The United States Government retains and the publisher, by accepting this article for publication, acknowledges that the United States Government retains a non-exclusive, paid-up, irrevocable, worldwide license to publish or reproduce the published form of this work, or allow others to do so, for United States Government purposes. 


\title{
Status of the Development of In-Tank/At-Tank Separations Technologies for High- Level Waste Processing for the U.S. Department of Energy
}

\author{
W. R. Wilmarth, ${ }^{1}$ N. P. Machara, ${ }^{2}$ S. P. Schneider, ${ }^{2}$ and R. A. Peterson ${ }^{3}$ \\ ${ }^{1}$ Savannah River National Laboratory, Aiken, SC, 29808 \\ ${ }^{2}$ U.S. Department of Energy, Office of Technology Innovation and Deployment (EM-31), \\ 19901 Germantown Road, Germantown, MD 20874 \\ ${ }^{3}$ Pacific Northwest National Laboratory, Richland, WA, 99352
}

Within the U.S. Department of Energy's (DOE) Office of Technology Innovation and Development, the Office of Waste Processing manages a research and development program related to the treatment and disposition of radioactive waste. At the Savannah River (South Carolina) and Hanford (Washington) Sites, approximately 90 million gallons of waste are distributed among 226 storage tanks (grouped or collocated in "tank farms"). This waste may be considered to contain mixed and stratified high activity and low activity constituent waste liquids, salts and sludges that are collectively managed as high level waste (HLW). A large majority of these wastes and associated facilities are unique to the DOE, meaning many of the programs to treat these materials are "first-of-akind" and unprecedented in scope and complexity. As a result, the technologies required to disposition these wastes must be developed from basic principles, or require significant re-engineering to adapt to DOE's specific applications. Of particular interest recently, the development of In-tank or At-Tank separation processes have the potential to treat waste with high returns on financial investment. The primary objective associated with In-Tank or At-Tank separation processes is to accelerate waste processing. Insertion of the technologies will (1) maximize available tank space to efficiently support permanent waste disposition including vitrification; (2) treat problematic waste prior to transfer to the primary processing facilities at either site (i.e., Hanford's Waste Treatment and Immobilization Plant (WTP) or Savannah River's Salt Waste Processing Facility (SWPF)); and (3) create a parallel treatment process to shorten the overall treatment duration.

This paper will review the status of several of the R\&D projects being developed by the U.S. DOE including insertion of the ion exchange (IX) technologies, such as Small Column Ion Exchange (SCIX) at Savannah River. This has the potential to align the salt and sludge processing life cycle, thereby reducing the Defense Waste Processing Facility (DWPF) mission by 7 years. Additionally at the Hanford site, problematic waste streams, such as high boehmite and phosphate wastes, could be treated prior to receipt by WTP and thus dramatically improve the capacity of the facility to process HLW. Treatment of boehmite by continuous sludge leaching (CSL) before receipt by WTP will dramatically reduce the process cycle time for the WTP pretreatment facility, while treatment of phosphate will significantly reduce the number of HLW borosilicate glass canisters produced at the WTP. These and other promising technologies will be discussed. 


\section{STATUS OF THE DEVELOPMENT OF IN-TANK/AT-TANK SEPARATIONS} TECHNOLOGIES FOR HIGH-LEVEL WASTE PROCESSING FOR THE

\section{U.S. DEPARTMENT OF ENERGY}

\author{
William R. Wilmarth \\ Savannah River National Laboratory \\ Aiken, South Carolina, 29808 USA \\ Phone (803) 725-1727 \\ Fax (803) 725-8829 \\ bill.wilmarth@srnl.doe.gov
}

\author{
Nicholas P. Machara \\ U.S. Department of Energy, \\ Office of Technology Innovation and \\ Deployment (EM-31), \\ 19901 Germantown Road, \\ Germantown, Maryland 20874 USA \\ Phone (301) 903-3327 \\ Fax (301) 903-4307 \\ nicholas.machara@em.doe.gov
}

\author{
Steve P. Schneider \\ U.S. Department of Energy, \\ Office of Technology \\ Innovation and Deployment \\ (EM-31), \\ 19901 Germantown Road, \\ Germantown, Maryland \\ 20874 USA \\ Phone (301) 903-7198 \\ Fax (301) 903-4307 \\ steve.schneider@em.doe.gov
}

\author{
Reid A. Peterson \\ Pacific Northwest National \\ Laboratory, \\ Richland, Washington 99352 \\ USA \\ Phone (509) 375-5386 \\ Fax (509) \\ reid.peterson@pnl.gov
}

\author{
Sheryl R. Bush \\ Savannah River National \\ Laboratory, \\ Aiken, South Carolina, 29808 \\ USA \\ Phone (803) 725-4997 \\ Fax (803)725-8829 \\ sheryl.bush@srnl.doe.gov
}

\begin{abstract}
:
Within the U.S. Department of Energy's (DOE) Office of Technology Innovation and Development, the Office of Waste Processing manages a research and development program related to the treatment and disposition of radioactive waste. At the Savannah River (South Carolina) and Hanford (Washington) Sites, approximately 90 million gallons of waste are distributed among 226 storage tanks (grouped or collocated in "tank farms"). This waste may be considered to contain mixed and stratified high activity and low activity constituent waste liquids, salts and sludges that are collectively managed as high level waste (HLW). A large majority of these wastes and associated facilities are unique to the DOE, meaning many of the programs to treat these materials are "first-of-a-kind" and unprecedented in scope and complexity. As a result, the technologies required to disposition these wastes must be
\end{abstract}

developed from basic principles, or require significant reengineering to adapt to DOE's specific applications. Of particular interest recently, the development of In-tank or AtTank separation processes have the potential to treat waste with high returns on financial investment. The primary objective associated with In-Tank or At-Tank separation processes is to accelerate waste processing. Insertion of the technologies will (1) maximize available tank space to efficiently support permanent waste disposition including vitrification; (2) treat problematic waste prior to transfer to the primary processing facilities at either site (i.e., Hanford's Waste Treatment and Immobilization Plant (WTP) or Savannah River's Salt Waste Processing Facility (SWPF)); and (3) create a parallel treatment process to shorten the overall treatment duration.

This paper will review the status of several of the R\&D projects being developed by the U.S. DOE including insertion 
of the ion exchange (IX) technologies, such as Small Column Ion Exchange (SCIX) at Savannah River. This has the potential to align the salt and sludge processing life cycle, thereby reducing the Defense Waste Processing Facility (DWPF) mission by 7 years. Additionally at the Hanford site, problematic waste streams, such as high boehmite and phosphate wastes, could be treated prior to receipt by WTP and thus dramatically improve the capacity of the facility to process HLW. Treatment of boehmite by continuous sludge leaching (CSL) before receipt by WTP will dramatically reduce the process cycle time for the WTP pretreatment facility, while treatment of phosphate will significantly reduce the number of HLW borosilicate glass canisters produced at the WTP. These and other promising technologies will be discussed.

\section{INTRODUCTION}

Technologies for at-tank or near-tank pretreatment of high-level waste (HLW) are being developed to accelerate waste processing at the Hanford and Savannah River sites. Insertion of the technologies will (1) create space in waste tanks and (2) treat problematic waste prior to transfer to the Defense Waste Processing Facility (DWPF) and Salt Waste Processing Facility (SWPF) at the Savannah River Site (SRS) and the Waste Treatment and Immobilization Plant (WTP) at Hanford.

At-tank or near-tank HLW pretreatment will dramatically enhance the performance of the HLW treatment systems. Deployment of systems to maximize tank space will enable the use of the safest tanks to expedite permanent waste disposition and allow for accelerated closure of the tanks with the greatest potential for leaking, reducing the long-term liability associated with those tanks. Treating problematic or opportunistic streams prior to receipt by DWPF, SWPF, and WTP as well as creating parallel treatment processes will significantly reduce the amount of material to be processed and the time required to process the balance of material through those large, expensiveto-operate facilities. These reductions in operating life time for the tanks and facilities translate directly into sizeable life-cycle risk reduction and cost savings.

\section{NOMENCLATURE}

Acronyms and abbreviations used in this paper include:

$\begin{array}{ll}\text { CSL } & \text { Continuous Sludge Leaching } \\ \text { CST } & \text { Crystalline SilicoTitanate } \\ \text { DOE } & \text { Department of Energy } \\ \text { DWPF } & \text { Defense Waste Processing Facility } \\ \text { EM } & \text { Office of Environmental Management } \\ \text { HLW } & \text { High-level waste } \\ \text { LAW } & \text { Low-activity waste } \\ \text { MCU } & \text { Modular Caustic Side Solvent Extraction Unit } \\ \text { MST } & \text { monosodium titanate } \\ \text { mMST } & \text { Modified MST }\end{array}$

$\begin{array}{ll}\text { NaSICON } & \text { Sodium (Na) Super Ionic CONductor membrane } \\ \text { NTCR } & \text { Near Tank Cesium Removal } \\ \text { NTTS } & \text { Near Tank Treatment System } \\ \text { PNNL } & \text { Pacific Northwest National Laboratory } \\ \text { R\&D } & \text { Research and development } \\ \text { RMF } & \text { Rotary Microfilter } \\ \text { SCIX } & \text { Small Column Ion Exchange } \\ \text { sRF } & \text { Spherical resorcinol formaldehyde } \\ \text { SRS } & \text { Savannah River Site } \\ \text { SVOC } & \text { Semi-volatile organic compound } \\ \text { SWPF } & \text { Salt Waste Processing Facility } \\ \text { TRL } & \text { Technical Readiness Level } \\ \text { WTP } & \text { Waste Treatment and Immobilization Plant }\end{array}$

\section{TECHNOLOGIES IN FINAL DESIGN}

Transformational acceleration of waste pretreatment will be realized by combining radiochemical separations into a single unit operation within waste tanks. National laboratories are maturing a combined ion-exchange and sorption process for intank removal of cesium, strontium, and select actinides from radioactive salt solutions.

\section{Small Column Ion Exchange}

Description - Small column ion exchange (SCIX) is a sorbent column system to remove cesium, strontium, and select actinides from radioactive salt solutions in waste tanks. The low-activity treated salt waste will be sent to an on-site disposal facility. The cesium-, strontium-, and actinide-laden sorbent material and the high-level waste (HLW) sludge will be sent to the on-site vitrification facility to be immobilized in glass for interim storage and eventual permanent disposition. Ideally, the SCIX module will be deployed in-tank, using existing waste tanks for shielding.

\section{$R \& D \quad$ Status - SCIX} deployment at Savannah River will utilize crystalline silicotitanate (CST), a nonelutable resin. The tank waste $R \& D$ is complete. However, additional work is now being performed under the contractor project scope. This work centers upon resuspension issues for long term storage in the tank farms and examines titanium-related issues

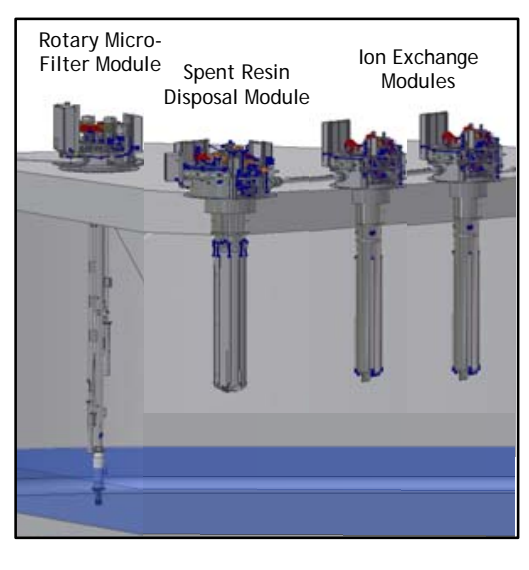
within DWPF. As for the Hanford deployment, a significant amount of R\&D has been conducted using the sRF resin in connection with qualifying the resin for WTP use. 
$R \& D$ Status - Current R\&D has been centered on the technical risks that arise from an in-riser design. These have included thermal modeling to establish temperature rises during routine and off-normal conditions, establishing the radiation stability of the sRF resin to limit the number of resin discharges from the in-riser design, and developing alternative eluants. The baseline eluant is nitric acid that is a potential corrosion concern due to the potential for non-routine discharges to the waste tank. If the desirable operation of SCIX is such that nitric acid is not employed, then determining the feasibility of an alternative eluent for the sRF resin is critical to the selection of the deployment design for SCIX.

Impact - Deployment of SCIX at the Savannah River Site (SRS) will expedite salt waste processing in advance of start-up of the SWPF now under construction, reducing the current lifecycle by about six years and \$3.6 billion. Deployment of SCIX at Hanford could enable retrieval and treatment of salt waste from single-shell tanks nearly a decade ahead of the pretreatment capabilities of the WTP now under construction.

\section{Modified Monosodium Titanate}

Description - SRS tank waste requires removal of strontium and actinides to meet the waste acceptance criteria of the Saltstone Disposal Facility. The SCIX process is effective for removal of cesium and to a lesser degree, strontium. However, the ion exchange material, CST, has little affinity for the actinide elements. Needed is a sorption material for deployment in a column configuration in combination with the ionexchange material.

$R \& D$ Status - Monosodium titanate (MST) is the identified material for strontium and actinide separations in operating and planned salt processing facilities, i.e., the Actinide Removal Process (ARP) and the Salt Waste Processing Facility (SWPF). Though effective for that purpose, MST, as a sorbent, has limitations including the rate of uptake of strontium and actinides limits facility throughput, and the quantity of MST used in facilities can adversely impact glass production in DWPF. Needed is an improved MST sorbent for the costeffective removal of strontium and alpha-emitting radionuclides from high-level nuclear waste solutions. The Savannah River National Laboratory has engineered a peroxide-modified MST material referred to as mMST that greatly improves the efficiency of the sorption process.

Impact - mMST improves throughput by three to four fold from 12-16 hours to 4 hours. Unlike MST, mMST does not pick up uranium, making available more binding sites for the targeted strontium and actinides.

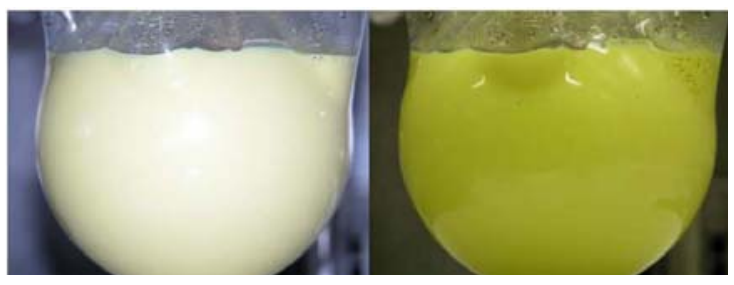

\section{Rotary Microfilter}

Description - Solid-liquid separation is one of the major bottlenecks in EM waste-processing operations. Needed are safe and cost-effective new approaches to increase the solidliquid separation rate in a radiological environment to increase process throughput. The identified advanced solid-liquid separation technology was the SpinTek ${ }^{\mathrm{TM}}$ rotary microfilter (RMF), a compact filtration system using membrane filters mounted on rotating disks. The rotary action of the filter produces high shear at the membrane surface, reducing the fouling of the membrane, thus producing higher filtrate flow rates than current technology. It also reduces the size and cost of filtration equipment.

$R \& D$ Status - To facilitate use in radiological environments, national laboratory investigators have made several modifications to the SpinTek ${ }^{\mathrm{TM}}$ RMF. Placing two rotary filters in a tank riser uses the existing waste tank for shielding, eliminating the need and cost to build a new shielded facility. The 250-piece original design has been modified to a single piece that can be installed and removed remotely. In addition, a patented method has been developed to weld the filter disk to the support disk, creating greater durability in a radiological environment. SRNL in collaboration with SpinTek Systems is testing the second-generation (2G) fullscale rotary microfilter for nuclear applications.

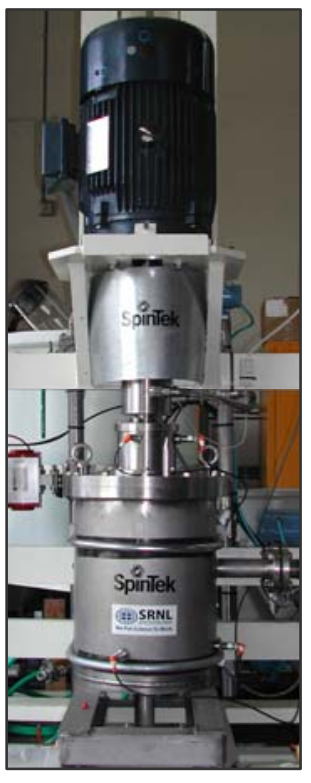

Impact - Deployment of 2G RMF will clarify salt waste feed to the sorbent column to expedite Small-Column Ion Exchange and enable continuous sludge washing to expedite preparation of high-level waste sludge batches for vitrification at SRS and may expedite processing of double-shell tank waste in conjunction with SCIX at Hanford.

\section{TECHNOLOGIES IN PILOT SCALE TESTING}

The objective of the Near Tank Treatment System (NTTS) is to provide an effective system to separate glass limiting aluminum and cesium from Hanford tank wastes, while minimizing added sodium, using one or more modular shielded systems that can be easily deployed near Hanford tanks. The system will comprise three modules: Continuous Sludge Leaching (CSL), Near Tank Cesium Removal (NTCR), and Sodium Recycle. The primary risk associated is the successful scale-up and integration of the individual units of the NTTS. 


\section{Continuous Sludge Leaching}

Description - Within Hanford's WTP, the HLW stream will require removal of nonradioactive hydrated aluminum oxides in the form of either gibbsite or boehmite sludge. Continuous sludge leaching (CSL) has been developed as a compact method for treating HLW sludge to dissolve the most difficult aluminum and chromium phases.

R\&D Status - Parsons, Richland, WA, fabricated a pilot-scale CSL demonstration unit to demonstrate the target aluminum and chromium dissolution in the CSL reactor; the effect of filtration temperature on filter flux; the effect of abrupt changes in the waste feed composition on system performance; and a control strategy to maintain the proper system operating performance under changing waste feed composition and flows by adjusting the reaction temperature, hydroxide concentration, filtration flow rates, and other parameters. Preliminary results indicate $60-70 \%$ removal of boehmite using a $5 \mathrm{M} \mathrm{NaOH}$ concentration and a $300 \mathrm{~h}$ residence time. This is a factor of 2 to 4 times higher fraction of boehmite dissolution than can be achieved in the WTP.

Impact - Treatment of boehmite by continuous sludge leaching CSL before receipt by WTP will dramatically reduce the process cycle time for the WTP pretreatment facility The selected treatment of the sludge in S and SX tank farms at Hanford will treat the majority of the difficult-to-leach aluminum and increase WTP throughput.

\section{Near-tank Cesium Removal}

Description - An effective and cost-efficient cesium ion exchange technology is needed to remove ${ }^{137} \mathrm{Cs}$ from lowactivity waste in an at tank application to supplement the WTP under construction at Hanford.

$R \& D$ Status - Developed at SRNL in the 1980s for cesium removal from alkaline high-level waste, resorcinol formaldehyde (RF) was pursued as a potential alternative to a trademarked, sole-sourced resin. RF is a ground gel, consisting of irregular ground particles. Ground gel RF displayed cesium ion exchange capacities comparable to the commercial product and was more stable in a radiation field; however, both resins displayed problematic hydraulic behavior in column conditions. For example, both shrank and swelled significantly when cycled between acid and base conditions. EM and national laboratories have tested and developed the application of a spherical form of RF, which, while somewhat less cesiumselective than the ground-gel RF or commercial resin, demonstrates superior hydraulic behavior. Its greater in-column stability leads to longer bed life in terms of number of cycles before resin disposal. The Near Tank Cesium Removal process takes advantages of these properties to utilize a streamlined processing scheme that will greatly reduce the foot print of an at tank deployment.

Impact - Establishing spherical RF as the baseline cesium ion exchange resin will enable WTP to operate with faster kinetics and less chemical degradation during cycling and storage, and to save significant $\$$ for resin procurement, use, and storage. Developing an at tank ion exchange system will significantly improve the throughput for the WTP. The current bottleneck in the WTP is the ability to pretreat the feed for immobilization. Deployment of the NTCR will alleviate that bottleneck.

\section{Electrochemical Caustic Recovery}

Description - The leaching process to remove sludge from HLW utilizes large amounts of sodium hydroxide. As the amount of sodium hydroxide approaches the base sodium in the HLW inventory, a technological need to develop methods to allow for recovery and recycling of the available caustic inventory to reduce the overall sodium load to the LAW feed is necessary. Needed is an electrochemical process to recycle sodium from the LAW stream. Ceramatec Inc., Salt Lake City, UT, has developed a process employs a sodium (Na) super ionic conductor membrane (NaSICON) to selectively remove sodium from LAW and supplemental waste streams under the influence of an electric field across the membrane. This allows for recycling of the caustic used to remove aluminum during sludge washing as a pretreatment step in the vitrification of radioactive waste and will allow reduction of the LAW waste volume by as much as $40 \%$. This technology will potentially reduce the handling and processing of waste and the time schedule at DOE sites. Potential cost savings in billions of dollars for waste cleanup may be realized by lowering the volume of waste. Implementing objectives include evaluating the technology benefits of tubular and planar membrane design configuration based on site process-flow requirements, robustness, and device reliability for application at WTP and developing a low-cost electrode.

$R \& D$ Status - Ceramatec has successfully demonstrated the NaSelect $^{\mathrm{TM}}$ (sodium super ionic conductor) ceramic membrane based electrolytic process to recycle sodium from several LAW simulants and actual wastes to generate "usable" sodium hydroxide for reuse onsite. This sodium recovery process allows for recycling of the caustic $(\mathrm{NaOH})$ used to remove aluminum during sludge washing as a pretreatment step in the vitrification of radioactive waste. The sodium recovery process will decrease the LAW volume by as much as 39\%. A technology demonstration scale unit (TDU) was successfully developed and demonstrated to process NTCR effluent feeding at $7 \mathrm{l} / \mathrm{hr}$ to make up to $30 \mathrm{wt} \%$ of sodium hydroxide. This process separated about $80 \%$ of sodium from the NTCR feed simulant before alumina precipitation was observed. Tens of thousands of hours of testing has been performed with the single and multiple prototypical cells to develop and scale up 
the design of the Caustic Recycling Unit to recycle sodium hydroxide from multiple simulant feed LAW compositions from Hanford site. The ability of the caustic recycling NaSelect ${ }^{\mathrm{TM}}$ membrane based process to recycle caustic from several simulant chemistries representative of actual wastes on site was successfully demonstrated. Based on testing with the single tubular membrane cell units, the prototype unit to configure multiple tubular membranes to handle higher feed throughput was developed. A sub-pilot scale modular system was designed, built and operated to process higher throughput of LAW simulant stream. Presently a Caustic Recycling Unit (CRU) is being built to recycle free sodium hydroxide from NTCR effluent as part of an integrated NTTS pilot demonstration with CSL and NTCR for reuse of caustic from the CRU process in the CSL process is in progress. The pilot scale system will process 16.6 liters per hour $(4.4 \mathrm{gal} / \mathrm{h})$ of NTCR effluent and generate 10M concentration of "usable" sodium hydroxide at 9.33 kilograms per hour. The safety and reliability factor to recover cells in case of gelling and precipitation of solids to meet the down bench-scale customdesigned cell containing three scaffolds, each with eight 2.4" NaSICON membranes.

Impact -Deployment of the Ceramatec Sodium Recovery System to Hanford will avoid import of fresh sodium hydroxide for both WTP and tank farm operations; ease operating constraints caused by trying to minimize sodium usage for caustic leaching, sludge flushing and hard heel removal; reduce the volume of immobilized low-activity waste (ILAW) produced by either fluidized bed steam reforming or vitrification; increase the waste loading of ILAW; decrease duration of operations due to decreased volume of waste processed; decontaminate recovered sodium hydroxide to the extent it can easily be handled with minimal radioactivity concerns or can be disposed of as a very low-level waste stream

\section{TECHNOLOGIES IN BEGINNING STAGES}

\section{Sulfate/Phosphate Removal}

Description - A problematic waste stream at the Hanford site is phosphate waste. Following caustic and oxidative leaching within WTP, the sludge is washed with the washwater being recycled to the front end of the pretreatment process. The issue is that during this washing, phosphate dissolves and reprecipitates with the addition of sodium.

A process needs to be developed to remove phosphate prior to transfer to the WTP. The primary risk associated with this task is the formulation of solids under various processing conditions that would cause process plugs, or upsets, or constrained operating conditions. The goal of this initiative is to demonstrate effective separation of phosphate to allow disposition of the phosphate-laden stream without further pretreatment.

$R \& D$ Status - Characterization of high phosphate wastes has been matured to the proof-of-principle stage. The first stage of phosphate-separation testing will be a series of simulant tests to identify candidate removal approaches. These tests will employ simulants developed based on recent characterization of the bismuth-phosphate wastes. From the simulant tests, a phosphate removal process will be selected and an actual waste demonstration test will be performed.

Impact - Treatment of phosphate prior to receipt by WTP will significantly reduce the volume of material that will be required to be processed by the ion exchange columns in WTP.

\section{CONCLUSION}

The development of At Tank or Near Tank pretreatment technologies for the treatment of high level waste (HLW) at Hanford and Savannah River sites provides potential solutions to: (1) maximize available compliant tank space to efficiently support permanent waste disposition including vitrification; and (2) treat problematic waste prior to transfer to either the Waste Treatment and Immobilization Plant (WTP) or Salt Waste Processing Facility (SWPF). Insertion of the technologies at Savannah River aligns the salt and sludge processing life-cycle, thereby eliminating the 7-year salt only campaign at Defense Waste Processing Facility (DWPF). At the Hanford site, problematic waste streams, such as high boehmite and phosphate wastes could potentially be treated prior to receipt by WTP and thus dramatically improve the capacity of the facility to process HLW.

\section{ACKNOWLEDGMENTS}

This work was prepared under an agreement with and funded by the U.S. Government. Neither the U. S. Government or its employees, nor any of its contractors, subcontractors or their employees, makes any express or implied:

1. Warranty or assumes any legal liability for the accuracy, completeness, or for the use or results of such use of any information, product, or process disclosed; or

2. Representation that such use or results of such use would not infringe privately owned rights; or

3. Endorsement or recommendation of any specifically identified commercial product, process, or service.

Any views and opinions of authors expressed in this work do not necessarily state or reflect those of the United States Government, or its contractors, or subcontractors.

\section{REFERENCES}

1. U.S. Department of Energy, Office of Environmental Management, Report to Congress: Report on Office of Technology Innovation and Development Program Plan, March 2010. 
2. U.S. Department of Energy, Office of Environmental Management, Technical Evaluation of Strategies for Transforming the Tank Waste System, January 2010, Washington, DC.

3. U.S. Department of Energy, Office of Environmental Management, Report to Congress: Status of Environmental Management Initiatives to Accelerate the Reduction in Environmental Risks and Challenges Posed by the Legacy of the Cold War, January 2009.
4. U.S. Department of Energy, Office of Environmental Management, Engineering and Technology Roadmap: Reducing technical Risk and Uncertainty in the EM Program, March 2008, Washington, DC.

5. Certa, P. J., Wells, M .N., River Protection Project System Plan, ORP-11242, Revision 4, September 2009,

6. Chew, D .P., Hamm, B.A., SRR-LWP-2009-00001, Liquid Waste System Plan, Revision 16, December 2010. 